[Agr. Biol. Chem., Vol. 36, No. 11, p. 2021 2024, 1972]

\title{
Decarboxylation of Oxalic Acid during Ripening of Banana Fruit (Musa sapientum L.)
}

\author{
By Keishi ShImoKawa, ${ }^{*}$ Yoshinori UedA ${ }^{* *}$ and Zenzaburo Kasal*** \\ * Faculty of Agriculture, Miyazaki Univ., Miyazaki, Japan, \\ ${ }^{*}$ Laboratory of Processing and Physiology of Horticultural \\ Products, University of Osaka Pref., Osaka, \\ *** The Research Institute for Food Science. \\ Kyoto University, Kyoto \\ Received April 3, 1972
}

Respiratory climacteric rise is well known as an important phenomenon in postharvest physiology of fruits, after which many fruits become edible. Attention has been centered to the mechanism of the climacteric rise. ${ }^{1 \sim 6\}}$ Hulme et al..$^{45}$ showed that the increase in enzyme activities results in the changes of the respiratory quotient during apple ripening. Wyman et al $^{6)}$ reported that oxalic acid was predominantly in unripe stage of banana fruit $(50 \%$ of total titrable acid) and the acid decreased gradually with ripening (about $60 \%$ of its original value). Thus, oxalic acid was suggested to be, contrary to vegetable plants, actively catabolized in ripening banana fruit, playing an important role in fruit ripening.

Oxalic acid occurs widely in a number of plants, $^{7 \sim 11}$ and its metabolic fate is well known in vegetable plants. But little is known about the fate of the acid during ripening of fruits.

In this report, participation of oxalic acid metabolism in the climacteric rise will be suggested from the studies on the metabolism of oxalate $-{ }^{14} \mathrm{C}$, and the effect of externally added oxalic acid on respiration.

Unripe bananas (Musa sapientum L.) were obtained from Kyoka Co. Ltd. at the Central Wholesale Market in Kyoto. They were kept at $20^{\circ} \mathrm{C}$ and occasionally sprayed with water. Three or four fingers from the same hand were transferred into a desiccator ( 7 litres) and the $\mathrm{CO}_{3}$ production was determined by $\mathrm{pH}$ change of sodium bicarbonate solution equilibrated with air passed through the desiccator. ${ }^{12}$ Relation between the respiratory

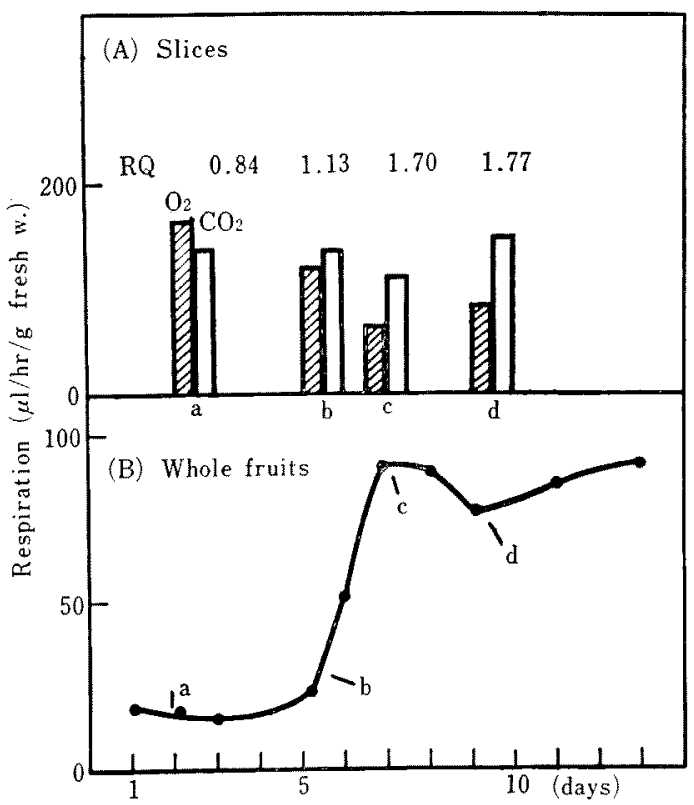

FIG. 1. Respiration ( $\mathrm{CO}_{2}$ production) of Slices (A) and Whole Fruits (B) of Banana Fruit.

Color and hardness of fruit during ripening, process indicated in Fig. 1 (B) are as follows: a, green hard, $b$, green soft; $c$, yellow with green tip; d, full yellow. 
rate and color change of the fruit during ripening is shown in Fig. 1. The respiratory rate of the slices $(2 \times 5 \mathrm{~mm}$ in diameter, $0.5 \mathrm{~g}$ in fresh weight) was determined by a manometric method at $30^{\circ} \mathrm{C}$. The slices were placed in main chamber containing $2 \mathrm{ml}$ of $0.1 \mathrm{M}$ potassium phosphate buffer, $\mathrm{pH} 6.8$ and $10 \mu$ moles of organic acid poured in a side arm.

Production of $\mathrm{CO}_{2}$ from sodium oxalate$1,2-{ }^{14} \mathrm{C}$ was also measured in homogenate of banana pulp. Fifty grams of banana pulp was macerated for $1 \mathrm{~min}$ using a mixer with $200 \mathrm{ml}$ of $0.1 \mathrm{M}$ potassium phosphate buffer, pH 6.2 containing $440 \mathrm{mg}$ of ascrobate. Homogenate $(2 \mathrm{ml})$ obtained as above was put into a Warburg flask containing $20 \% \mathrm{KOH}$ in a center well (with $2 \times 2 \mathrm{~cm}$ filter paper) and sodium oxalate-1,2- ${ }^{14} \mathrm{C} \quad(0.1 \mu \mathrm{Ci}, \quad 0.3 \mathrm{ml}$ in volume, with $5 \mu$ moles of sodium oxalate as carrier) in a side arm. These vessels were incubated at $30^{\circ} \mathrm{C}$. Reaction was started by the addition of oxalate to the reaction mixture, and after a desired incubation period, stopped by addition of $\mathrm{H}_{2} \mathrm{SO}_{4}$. Absorbed ${ }^{14} \mathrm{C}$ into a piece of filter paper in a center well was directly counted with a liquid scintillation counter. The value was corrected for counting efficiency.

Production of $\mathrm{CO}_{2}$ and color change in the fruit are shown in Fig. 1 (B). While $\mathrm{CO}_{2}$ evolution of the whole fruit showed a typical climacteric rise, there was no significant climacteric rise in the case of the slices (Fig. 1 (A)). Respiration quotient (RQ) in the respiration of the slices changed from 0.84 to 1.77 during ripening. Therefore it is assumed that substrate responsible for $\mathrm{CO}_{2}$ evolution changes with the progress of ripening, and that the decarboxylation of oxalate, pyruvate and malate is an origin of $\mathrm{CO}_{2}$ evolution at later stage of ripening as suggested by Hulme et al. ${ }^{4)}$

Effect of addition of oxalate, pyruvate and

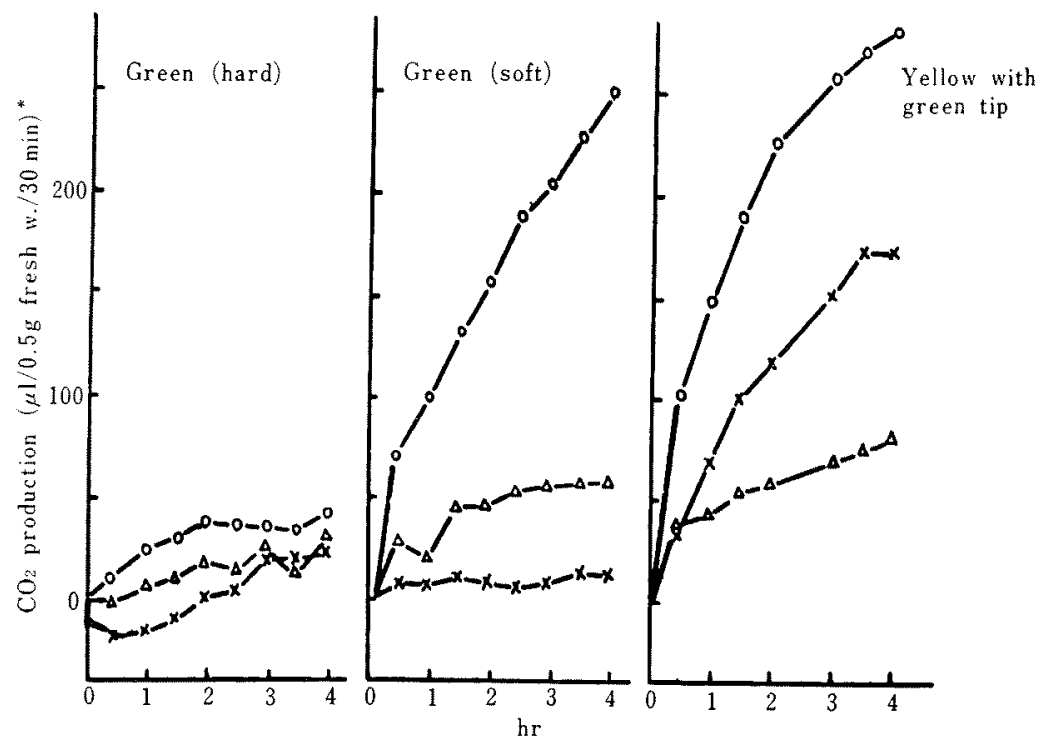

FIG. 2. Production of $\mathrm{CO}_{2}$ by Banana Slices after Addition of Oxalate, Pyruvate and Malate at Different Stages of Ripening.

O-O Oxalate, $x-\times$ Pyruvate, $\Delta-\Delta$ Malate,

* Corrected for endogenous $\mathrm{CO}_{2}$ production. 


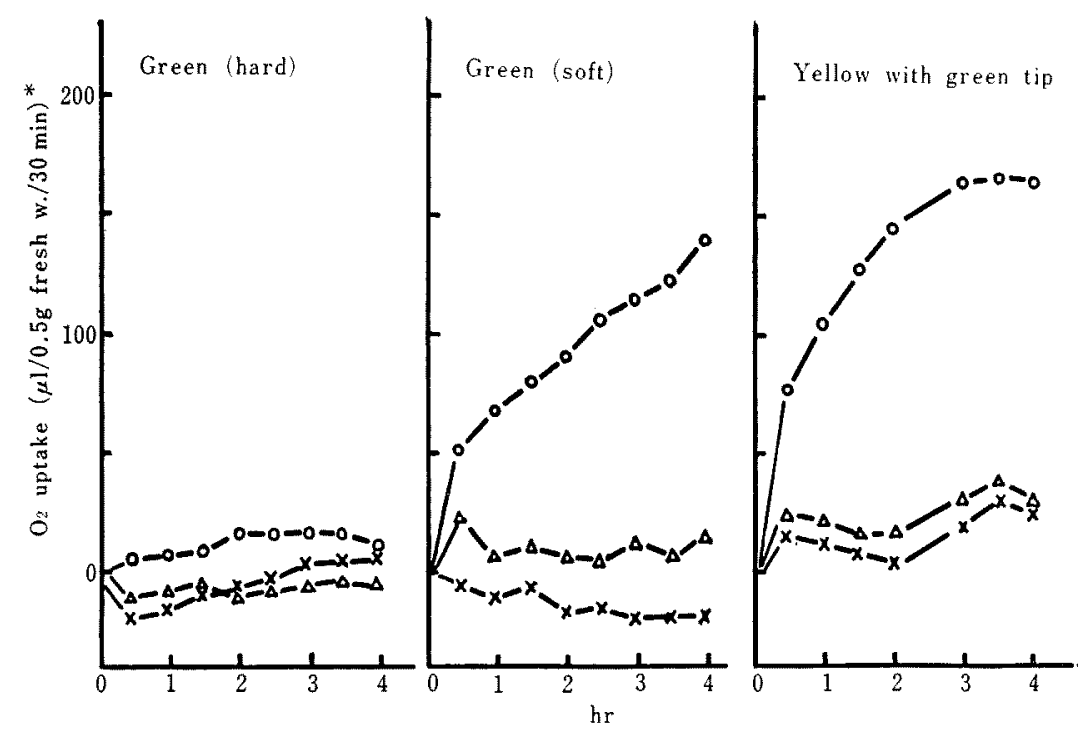

FIG. 3. $\mathrm{O}_{2}$ Uptake by Banana Slices after Addition of Oxalate, Pyruvate and Malate at Different Stages of Ripening.

O-O Oxalate, $x-x$ Pyruvate, $\Delta-\Delta$ Malate.

* Corrected for endogenous $\mathrm{O}_{2}$ uptake.

malate to the slices of banana pulp on $\mathrm{CO}_{2}$ evolution and $\mathrm{O}_{2}$ uptake are shown in Figs. 2 and 3 , respectively. At the green hard stage, those organic acids were not metabolized. However, oxalate was significantly decarboxylated as soon as the fruit reached the stage of green soft. Thus it is indicated that oxalic acid is one of $\mathrm{CO}_{2}$ source at the stage of climacteric rise. Decarboxylation of oxalic acid was accompanied by $\mathrm{O}_{2}$ uptake, in contrast with the cases of malic and pyruvic acids, where the increase in $\mathrm{O}_{2}$ uptake was not observed.

As shown in Figs. 2 and 3, the addition of oxalic acid to the slices resulted in $\mathrm{CO}_{2}$ evolution and $\mathrm{O}_{2}$ uptake, suggesting that the decarboxylation of oxalate is carried out by an oxalate oxidase. Evolution of ${ }^{14} \mathrm{CO}_{2}$ (Fig. 4) from oxalate-1, $2-{ }^{14} \mathrm{C}$ by the homogenate from the banana pulp at two stages of ripening was in good agreement with the results of Fig. 2. The results suggested that nonavailability of oxalate by the slices of banana

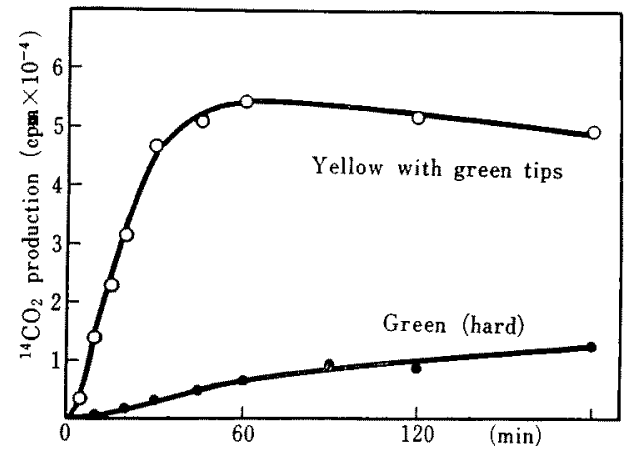

FIG. 4. Production of ${ }^{14} \mathrm{CO}_{2}$ from Oxalate-1,2-14 $\mathrm{C}$ in Banana Pulp Homogenate Obtained from Different Ripening Stages.

Cold oxalate ( $5 \mu$ moles) was added as carrier. See text for preparation of homogenate. Direct count of oxalate-1,2-14 $\mathrm{C}(0.1 \mu \mathrm{Ci})$ soaked into filter paper $\left(\mathrm{CO}_{2}\right.$ absorber in center well of Warburg vessel) was about $7 \times 10^{4} \mathrm{cpm}$. These counting values were corrected for quenching effect.

pulp at an early stage of ripening was not due to a barrier of permeability. Further the boiled homogenate at those stages of ripening evolved no ${ }^{14} \mathrm{CO}_{2}$ for $30 \mathrm{~min}$, indicating that 
the decarboxylation of oxalate is an enzymatic reaction.

Banana fruits have astringent taste in unripe stage. However, after respiratory climacteric peak, the taste disappears, and fruits become edible. It is well known that oxalic acid is one of the astrigent materials, and this may be the essence of the astringent taste in banana.

It would be interesting to know more about a mechanism of the oxalic acid decarboxylation at the onset of fruit ripening in banana.

\section{REFERENCES}

1) J. B. Biale, Adv. Food Res., 10, 293 (1960).

2) J.B. Biale, Handbuch der Pfanzenphysiol., 12,
$536(1960)$.

3) J. B. Biale and R. E. Young, Endeavor, 21, 164 (1962).

4) A. C. Hulme, J. D. Jones and L. S. C. Wooltorton, Proc. Roy. Soc. (London), Ser. S., 158, 514 (1963).

5) A. C. Hulme, Adv. Food Res., 8, 297 (1958).

6) H. Wyman and J. K. Palmer, Plant Physiol, 39, 630 (1964).

7) K. Sasaki, Botan. Mag., (Tokyo), 76, 48 (1963).

8) R. L. Clements, J. Food Sci., 29, 276 (1964).

9) L. H. Jones, Can. J. Botany., 39, 593 (1961).

10) H. A. Blundstone and D. Dickinson, J. Sci. Food Agr., 15, 94 (1964).

11) M. Kusama, H. Murakami and Y. Kidokoro, Eiyogaku Zasshi, 21, 41 (1963).

12) L. L. Claypool and R. M. Keefer, Proc. Amer. Soc. Sci., 40, 177 (1942). 